\title{
Duramazwi reDudziramutauro neUvaranomwe against the Background of Shona Lexicography
}

Gift Mheta, Department of Linguistics, University of the Western Cape, Bellville, Republic of South Africa (2971565@uwc.ac.za) and

Maxwell Kadenge, Department of Linguistics, School of Literature and Language Studies, University of the Witwatersrand, Johannesburg, Republic of South Africa (maxwell.kadenge@wits.ac.za)

\begin{abstract}
This article considers and analyses Duramazwi reDudziramutauro neUvaranomwe (henceforth DRU), a 2007 product of the University of Zimbabwe's African Languages Research Institute (ALRI). It evaluates DRU which is the first terminological dictionary dealing with Shona literary and linguistic terms. Furthermore it traces the compilation process of this dictionary, describing the stages of collection, selection, entry and definition of terms. It also examines the microstructure and the macrostructure of DRU aimed at target users who are both students and teachers in high schools and tertiary institutions offering Shona as a subject or course.
\end{abstract}

Keywords: BILINGUAL, COLLECTION, COMPILATION, COMPUTATIONAL, CORPUS, DEFINITION, DEVELOPMENT, ENTRY, HEADWORD, LEXICOGRAPHY, LINGUISTIC, LITERARY, MACROSTRUCTURE, MICROSTRUCTURE, MONOLINGUAL, SELECTION, TERMINOLOGY

Opsomming: Duramazwi reDudziramutauro neUvaranomwe teen die agtergrond van Sjonaleksikografie. Hierdie artikel beskou en ontleed Duramazwi reDudziramutauro neUvaranomwe (voortaan DRU), 'n 2007 produk van die Universiteit van Zimbabwe se African Languages Research Institute (ALRI). Dit beoordeel DRU wat die eerste terminologiese woordeboek is wat Sjona- literêre en linguistiese terme behandel. Verder gaan dit die samestellingsproses na deur die stadiums van versameling, keuse, inskrywing en definiëring van terme te beskryf. Dit ondersoek ook die mikrostruktuur en die makrostruktuur van DRU, gerig op teikengebruikers wat sowel studente as opvoeders in hoërskole en tersiêre instellings is wat Sjona as ' $n$ vak of kursus aanbied.

Sleutelwoorde: TWEETALIG, VERSAMELING, SAMESTELLING, REKENAAR-, KORPUS, DEFINISIE, ONTWIKKELING, INSKRYWING, TREFWOORD, LEKSIKOGRAFIE, LINGUISTIES, LITERÊR, MAKROSTRUKTUUR, MIKROSTRUKTUUR, EENTALIG, KEUSE, TERMINOLOGIE 


\section{Introduction}

According to Kipfer (1984), lexicography is the study and practice of dictionary-making. A broad definition that transcends the stress placed on dictionarymaking to include other related activities is well expressed by Svensén (1993: 1) when he says:

Lexicography is a branch of applied linguistics which consists in observing, collecting, selecting and describing units from the stock of words and word combinations in one or more languages ... Lexicography also includes the development and description of theories and methods which are to be the basis of this activity.

Lexicography contributes significantly to terminology development in languages (Mheta 2007: 11). As noted by the National Language Policy Advisory Panel (1998: 44), one area of linguistic research that is now recognized internationally as being important for language standardization and development is lexicography or dictionary-making. Traditionally, standardization is viewed as involving the twin process of codification, that is, making rules about the writing system, and grammar and elaboration, which refers to expanding and intellectualizing the vocabulary and diversifying the functions of the language so that it becomes an effective tool for communication even in specialized fields such as literature and linguistics, with which this article deals. The National Language Policy Advisory Panel further mentions that in both these processes, a standard dictionary has an important normative influence, as its users will accept and apply the lexicographers' descriptions of word-forms and their statements on their meanings. Having noted the importance of language standardization, which includes terminology development, it is necessary to trace the history of Shona lexicography that has positively contributed to Shona terminology development.

\section{Background}

The Shona language has a lexicographic history of nearly one and half centuries. It stretches back to the period preceding the arrival of the Pioneer Column and the establishment of Southern Rhodesia by the British South Africa Company when writings on the Shona language in English and compilations of Shona vocabulary are already found, such as the first bilingual dictionary in Shona and English, The Languages of Mosambique (1856) by Bleek, which was followed by Elliot's Dictionary of the Ndebele and Shona Languages (1887) and Hartmann's English-Mashona Dictionary (1894) (see Doke 2005). Ever since then, the trend has been that of compiling bilingual linguistic dictionaries. The most popular of these dictionaries is Hannan's Standard Shona Dictionary published in 1959 and subsequently revised in 1984. The trend of compiling bilingual dictionaries continued until 1996 when the African Languages Lexical (ALLEX) Project, then housed in the Department of African Languages and Literature at 
the University of Zimbabwe, produced the first-ever monolingual Shona dictionary, Duramazwi reChiShona. This was followed in 2001 by Duramazwi Guru reChiShona (hereafter DGR) which is an advanced Shona monolingual dictionary. Since the publication of this dictionary, there has been a paradigm shift in Shona lexicography, from the production of general linguistic dictionaries to the compilation of specialized dictionaries. Examples of Shona specialized dictionaries are Duramazwi reUrapi neUtano, a dictionary of biomedical terms published in 2004, and Duramazwi reMimhanzi, a dictionary of musical terms published in 2005. The most recent terminological dictionary in Shona is Duramazwi reDudziramutauro noUvaranomwe (hereafter DRU), dealing with Shona literary and linguistic terms and published in 2007. Currently there are also running projects on dictionaries in specialized fields such as Duramazwi Guru reMimhanzi (an advanced Shona musical terms dictionary) and a Shona medical terms dictionary. The two are sub-projects of the NUFU-funded Cross-border Languages Project that is a network project that involves researchers at the African Languages Research Institute (ALRI), the Eduardo Mondlane University in Mozambique and the University of Oslo in Norway. It is in the context of these lexicographic activities that Shona terminology development will be discussed.

Despite the relatively long lexicographic history, the Shona language is still very much like other African languages in lacking adequate terminology in specialized fields. Like many indigenous languages in Africa, there are many problems that are unconducive to the effective use of Shona in specialized fields, one of the major ones being the absence of standard terminology in technical areas. Discussing the problem of terminology development in Ndebele, Hadebe (2006) states that the language situation in Zimbabwe, where African languages are confined to the unofficial domains, has led to an underdevelopment of terminology in almost all fields. This is a true reflection of the current status of the Shona language as well, and the general situation of indigenous languages in most African countries. For example, Shona is still taught in English at the University of Zimbabwe, the oldest and largest academic institution in Zimbabwe. The reason for this is that terminology for teaching Shona has not been standardized. Tertiary institutions have been using different terms to refer to the same literary and linguistic concepts. The rectification of this anomaly necessitated the compilation of DRU.

To appreciate fully why DRU may be considered important in the development of Shona lexicography, it is necessary to look at the procedures followed by the ALRI lexicographic team that culminated in the successful compilation of this dictionary. How the different stages of collection, selection, entry and definition took place will be described in the following sections.

\section{Collection}

Although DRU is the first dictionary of its kind, previous Shona dictionaries were used as sources for collecting terms for it. These dictionaries include Dale 
(1981), Hannan (1984), Chimhundu (1996, 2001), Mpofu et al. (2004), Mheta (2005) and ZIMSEC/CDU (2006). They provided the bulk of the headwords found in DRU.

Apart from dictionaries, headwords were also collected from books used in teaching Shona literature and grammar in secondary and high schools, teachers' colleges and universities. Such books include Doke (1931, 2005), Fortune $(1955,1972)$, Chimhundu $(1995,1998,2000)$ and Magwa (1999).

Other headwords were drawn from the African Languages Lexical Project (ALLEX) Shona corpus. According to Crystal (1997: 95), a corpus refers to a collection of linguistic data, either written texts or a transcription of recorded speech, which can be used as a starting-point for linguistic description or as a means of verifying hypotheses about a language. A similar definition is given by Kennedy (1998: 1), who describes a corpus as "a body of written text or transcribed speech which can serve as a basis for linguistic analysis and description". The ALLEX Shona corpus is more than just a written text. It is a systematic, well-designed and -selected collection of written texts and transcribed speech in electronic form. In corpus linguistics terms, it is a dynamic or monitor corpus, i.e. an open-ended machine-readable corpus (see Kennedy 1998: 22.) It is an example of what Sinclair (1992: 382) calls "huge, changing bodies of no finite size, flowing across a set of filters which extract linguistic evidence". It was collected by members of the ALLEX project when it compiled the first corpus-aided monolingual dictionary, Duramazwi reChiShona (1996). The collection of the data for the corpus started in 1993 and continues to the present day for purposes of producing more lexicographic projects at ALRI and facilitating other research activities in the Shona language. The Shona corpus, which has 2962412 tokens or running words is composed of both written and oral materials from various genres collected from all the Shona-speaking districts of Zimbabwe. The Shona corpus includes Shona literary and linguistic terms. Below is an excerpt adapted from the ALLEX Shona corpus.

ALRI SHONA corpus (2 962 412)

Search for ".*uvaranomwe" in SHONA

12 hits (limited to 1000 )

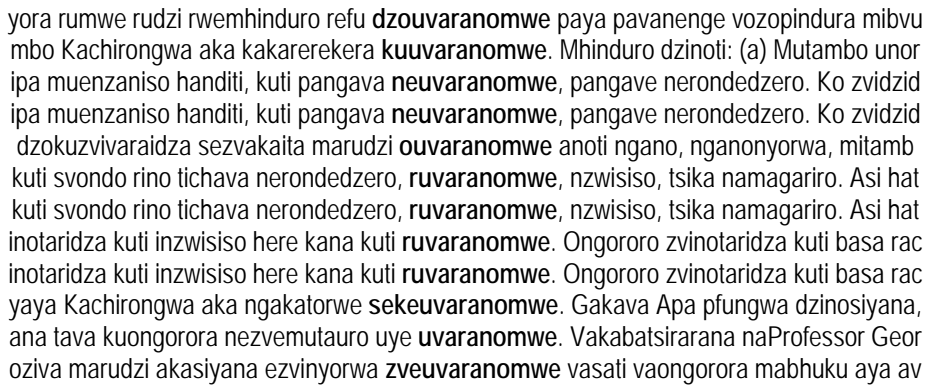


Apart from relying on written sources, both hard copies and electronic versions, the ALRI lexicographic team had to assemble a reference working group (hereafter RWG) from which it obtained more Shona literary and linguistic terms. The RWG comprised Shona language experts from universities. In this regard, experts were drawn from the University of Zimbabwe in Harare, Great Zimbabwe State University in Masvingo and Midlands State University in Gweru. Lecturers were also drawn from teachers colleges such as Hillside in Bulawayo, Bondolfi in Masvingo, Marymount in Mutare and Seke in Chitungwiza. Shona teachers from different provinces in Zimbabwe furthermore formed part of the RWG. The ALRI lexicographic team benefited from this group of Shona language experts because various members of this group represented different institutions and every institution had its own set of Shona literary and linguistic terms. From the RWG it emerged that different terms were used by different institutions to refer to the same literary and linguistic concepts. For example, some institutions used mapishapisha while others preferred makakatanwa to refer to 'conflict'. Other examples are given in the following table:

\begin{tabular}{|l|l|l|}
\multicolumn{1}{|c|}{$\begin{array}{c}\text { Shona Terms at } \\
\text { Institution A }\end{array}$} & \multicolumn{1}{c|}{$\begin{array}{c}\text { Shona Terms at } \\
\text { Institution B }\end{array}$} & \multicolumn{1}{c|}{ English Gloss } \\
\hline dendavabatsiri & nhendo & acknowledgements \\
\hline hweretwa & izwi rokutapa & adoptive \\
\hline chidudzirachiito chewadzano & chidudzirachiito chekuita pamwe & adverb of association \\
\hline nhoredzera yenyaudzira & mutinhirosiri & allophone \\
\hline pikisadudziro & izwi rokupikisa & antonym \\
\hline wirirano & sungawirirano & concordial agreement \\
\hline tsoropodzo & ongororo & critique \\
\hline chiitomwana & chiitogama & defective verb \\
\hline nganonyorwa yoruferefeto & nganonyorwa yorufefeto & detective novel \\
\hline izwi guru & izwi simboti & head word \\
\hline
\end{tabular}

It should be noted that in some instances a single literary or linguistic concept could be signified by five or even more different signifiers. For example, turabefu, chifema, chiturabefu, chituramafemo, koma and nhurabefu are different words used by different academic institutions to refer to 'comma'. Another term that yielded different representations from different academic institutions is 'auxiliary verb', as shown, for example, by the following words: chiitobatsiri, chiitomhini, chiitogasva, chiitogama and chiitomwana.

Different institutions represented in the RWG meant that the ALRI lexicographic team ended up collecting many headwords from the group of Shona language experts. At this stage, diversity was an advantage and not a challenge because the target for the lexicographic team was to collect as many literary and linguistic terms as possible. The challenge of dealing with diversity emerged at the selection stage. 


\section{Selection}

With a set target of 1500 Shona headwords, it meant that the ALRI lexicographic team had to select the most relevant literary and linguistic terms from the collection they had brought together. The selection was done with the assistance of the RWG. It was through discussions with members of the RWG that the ALRI lexicographic team managed to select the main headwords. As already mentioned in the previous section, the lexicographers had to contend with the challenge of different headwords used to refer to the same literary and linguistic concepts by different institutions. In response to this challenge the lexicographers together with the RWG selected the main headwords on the basis of frequency and acceptability. For example, demberezeze referring to the literary term 'suspense' was more frequent in the various institutions represented in the RWG than dokwaidzo. For this reason, the former was selected as the main headword that carries the definition and the latter as a synonym as is demonstrated in the excerpt from DRU (p. 51) below:

demberezeze D- z 5 (suspense). Aya manyorerwo enyaya kana maburitsirwo echionwa anoita kuti vaverengi, vaoni kana vateereri vave nechidokwadokwa kana havi yokuda kuziva kuti chii chakazoitika muchinyorwa, chionwa kana nhaurwa. FAN dokwaidzo 9.

demberezeze L- $\mathrm{n}$ cl. 5 (suspense). This is a way of writing a story or showing a film that retains the interest of the readers, listeners or viewers. SYN dokwaidzo 9 .

In instances where Shona literary or linguistic terms were found in the ALLEX corpus the frequency of terms in the corpus was compared to that which became apparent from discussions with the RWG. A consensus was always reached as members of the RWG were constantly reminded not to be regional defenders but to base their selections on facts and figures.

\section{Entry}

Of interest in this section is how grammatical information for headwords was entered in DRU. The ALRI lexicographic team agreed to mark tone, and indicate grammatical category and class of headwords. For example, the headword demberezeze given above in the previous section is a class 5 noun as indicated by $\mathrm{z} 5$ that has a low tone throughout as shown by D-. To this end, the grammatical information for the headwords was shown using the format found in general linguistic dictionaries such as DGR. What comes as an innovation in this dictionary is the morphological description of each formative that is part of the headword. For example, the formatives that compose the headword chiratidzakure are presented as follows in DRU (p. 28):

chiratidzakure [chitaridzakure] D- z 7 (far demonstrative) <-ratidz-a + kure. 
In this case, the reader is informed that the headword chiratidzakure comes from -ratidz, a verb radical that means 'show' and kure an adverb of place that means 'far'.

Therefore, the added advantage DRU has over general linguistic dictionaries is that it offers a more complete description of entries. Even before the users come to the definition, they will have an idea of the meaning of the headword. In a way, the additional morphological information complements the definitions.

\section{Definition}

The ALRI lexicographic team encountered a number of challenges at the definition stage. The most difficult task was how to construct a framework that would assist in composing definitions of the terms with more encyclopedic information than those found in general linguistic dictionaries. Since DRU is encyclopedic in nature, the team had to frame definition guidelines that would ensure the inclusion of most of the encyclopedic information. For instance, definitions for terms on oral literature such as types of dances had to indicate

(a) whether the dance is traditional or modern,

(b) the origin and region where it (especially when traditional) is found,

(c) the performer(s) of the dance as well as its context and the time of its performance,

(d) the costumes worn, equipment used or instruments played, and

(e) the type of music involved.

With clearly spelt out definition formats it became easy for the team to draft exhaustive definitions contrasting with the concise ones found in general linguistic dictionaries. A comparison of two definitions, one from DGR and the other from DRU clearly illustrates this point.

Definition from DGR (p. 714):

ngano D- z $9>10$. Ngano inyaya inorondedzera zvakaitika kare, zvingave zvechokwadi kana zvisingakwanisi kuitika. FAN rungano 11. Ngano inyaya isingabvumwi nemunhu anenge achiudzwa. Dai wangonditaurirawo chokwadi. Kwete ngano dzauri kundiudza idzi.

ngano L- $\mathrm{n} \mathrm{cl.} 9>10$. A folktale is a story that relates what happened in the past, which might be fantasy or fact. SYN rungano 11. A folktale is a story that the listener does not believe. Just tell me the truth and not folktales.

Definition from DRU (p. 116)

ngano D- z $9>10$. Ngano inyaya inotaurwa nasarungano achirondedzera zvakaitika kare, zvingave zvechokwadi kana zvisiri zvechokwadi, kana kutoti 
zvisingakwanisi kuitika. Ngano dzinowanzotaurirwa kuvana vadiki nechinangwa chokuvadzidzisa nokuvatandadza. Makarekare ngano dzaiitwa muchirimo munguva dzemanheru, vanhu vapedza chisvusvuro chemanheru. Zvidzidzo zvomungano zvinobva muzvinhu zvinenge zvakaitika kune mumwe munhu, asi vatambi vacho vanogona kunge dziri mhuka dzinogona kutaura nokuita zvose zvinoitwa nevanhu. Kune ngano dzine vatambi vanenge vachingova vanhu, dzimwewo dzine vatambi vanenge vari mhuka, kozoti dzimwewo dzinosanganisa vatambi vevanhu nevemhuka, nedzimwe dzimwezve dzine vanhu vanoshanduka kuita mhuka; asi vatambi vese ivava vanenge vachikwanisa kutaurirana sevanhu. Muzviitiko netsaona dzinopinda vatambi vakasiyana-siyana ndimo munobuda zvidzidzo pamusoro pezvinofanira kuitwa nezvisingafaniri kuitwa muupenyu. Saka vateereri vengano kana kuti vana vadiki vanenge vachitodzidziswa pamusoro petsika nokugarisana kwakanaka. FAN rungano.

ngano L- $\mathrm{n}$ cl. $9>10$. A folktale is a story told by a story-teller, which may be fantasy or fact. Folktales are usually told to children with the intention of teaching and entertaining them. Long ago, folktales were told during the dry season, in the evening, after supper. Lessons in folktales come from what happens to people but the characters in folktales can either be human beings or animals or a combination of both. In folktales, animal characters speak like human beings. In some cases, human beings change into animals. Lessons are drawn from the events that take place in the folktales. In this regard, children are taught their culture through folktales.

The abundance of information on literary and linguistic terms shows that the DRU lexicographic team successfully framed definition guidelines which have helped in presenting as much encyclopedic information as possible. For example, the definition for ngano in DGR is concise but the one in DRU is elaborate as it gives almost every finer detail about the headword. It should also be noted that while DGR only defines the headword ngano DRU goes a step further by defining the various types of ngano, such as ngano dzakanyorwa and ngano dzinotaurwa given as separate headwords.

\section{Additional Information in the Dictionary}

Unlike other general literary and linguistic dictionaries, DRU has an index at the end of the Aa-Zz dictionary section. The index contains English literary and linguistic terms and their Shona equivalents. This section is of great value to readers who wish to quickly look up Shona equivalent terms for English literary and linguistic terms they know without having to refer to the definitions. In addition, it has a grammar section, which comprises explanations of grammatical categories such as nouns, verbs, ideophones and orthographic rules for the Shona language. To this end, the dictionary contains almost every important aspect of the Shona language. 


\section{Conclusion}

The discussion of DRU shows that the dictionary is indeed an asset to the educational sector in Zimbabwe, which had hitherto lacked adequate and relevant Shona written materials with standardized terminology on literature and linguistics. It is a dictionary that testifies that any specialized area can be taught in the Shona language. It also confirms the fact that all languages, being equally complex, can be used to express any idea. Like any other venture, terminological development in African languages is a big but not insurmountable challenge. The objective of teaching any specialized field in an indigenous language is attainable as evidenced by the publication of DRU which is indeed of importance in the development of the Shona language. It will go a long way in assisting both students and teachers in the mastery of the intricacies of the Shona language.

\section{References}

Bleek, W.H.I. 1856. The Languages of Mosambique. London: Harrison.

Chimhundu, H. 1995. Zambuko 3. Harare: College Press.

Chimhundu, H. 1996. Duramazwi reChiShona. Harare: College Press.

Chimhundu, H. 1998. Zambuko 4. Harare: College Press.

Chimhundu, H. 2000. Zambuko 3 \& 4: Bhuku roMudzidzisi. Harare: College Press.

Chimhundu, H. 2001. Duramazwi Guru reChiShona. Harare: College Press.

Chimhundu, H. 2005. Lexicography and Language Raising: Dictionaries in Zimbabwean Languages. Public lecture presented as part of the Golden Jubilee Celebrations of the University of Zimbabwe, Harare, 13 April 2005.

Chimhundu, H. and E. Chabata. 2007. Duramazwi reDudziramutauro noUvaranomwe. Gweru: Mambo Press.

Crystal, D. 1997. A Dictionary of Linguistics and Phonetics. Fourth Edition. Oxford: Basil Blackwell.

Dale, D. 1981. Duramazwi: A Shona-English Dictionary. Gweru: Mambo Press.

Doke, C.M. 2005. Report on the Unification of Shona Dialects. A Photographic Reprint with an Introduction by H. Chimhundu. Oslo: ALLEX Project.

Elliot, W.E. (Ed.). 1887. Dictionary of the Ndebele and Shona Languages. London: David Nutt.

Fortune, G. 1955. An Analytical Grammar of Shona. Cape Town/New York/London: Longmans, Green.

Fortune, G. 1972. A Guide to Shona Spelling. Salisbury: Longmans.

Hadebe, S. 2006. The Standardisation of the Ndebele Language through Dictionary-Making. Harare/ Oslo: The ALLEX Project.

Hannan, M. 1959. Standard Shona Dictionary. Harare: Literature Bureau.

Hannan, M. 1984. Standard Shona Dictionary. Revised Edition with Addendum. Harare: College Press.

Hartmann, A.M. 1894. English-Mashona Dictionary. Cape Town: Juta.

Kennedy, G. 1998. An Introduction to Corpus Linguistics. London/New York: Longman. 
Kipfer, B.A. 1984. Workbook on Lexicography: A Course for Dictionary Users with a Glossary of English Lexicographical Terms. Exeter: University of Exeter.

Magwa, W. 1999. Manyorerwo eChiShona. Gweru: Mambo Press.

Mheta, G. 2005. Duramazwi reMimhanzi. Gweru: Mambo Press.

Mheta, G. 2007. Strategies Employed in the Development of Shona Musical Terms. Unpublished M.Phil. Thesis. Harare: University of Zimbabwe.

Mpofu, N. 2004. Duramazwi reUrapi neUtano. Gweru: Mambo Press.

National Language Policy Advisory Panel. 1998. Report on the Formulation of a National Language Policy. Harare: Ministry of Education, Sport and Culture.

Sinclair, J.M. 1992. The Automatic Analysis of Corpora. Svartvik, J. (Ed.). 1992. Directions in Corpus Linguistics: Proceedings of Nobel Symposium 82, Stockholm, August 4-8, 1991. Berlin: Mouton de Gruyter.

Svensén, B. 1993. Practical Lexicography: Principles and Methods of Dictionary-Making. Oxford: Oxford University Press.

ZIMSEC/CDU. 2006. Duramazwi reZvidzidzo zveChiShona. Harare: ZIMSEC.

\section{Websites}

The African Languages Research Institute. Available at: http://www.uz.ac.zw/alri/. 